\section{RELATIONSHIP BETWEEN DIET CHRONIC ENERGY LACK IN PREGNANT WOMEN IN TRIMESTER}

\author{
Saddiyah Rangkuti \\ Universitas Haji Sumatera Utara
}

\begin{abstract}
Chronic lack of energy can occur in pregnant women in the first trimester. Because in the first trimester, the mother's appetite generally decreases, due to frequent nausea and vomiting (morning sickness). Nutrition of pregnant women is influenced by several factors, one of which is diet. This study aims to determine the relationship between diet and Chronic Energy Deficiency in first trimester pregnant women at Pagurawan Health Center, Batu Bara Regency in 2020. This type of research is a quantitative research with a descriptive correlation design with a cross sectional approach. The type of data used is primary data and secondary data collected using a questionnaire sheet and then processed and analyzed using the chi-square test.The results showed that through statistical tests using the chi-square test, the p-value was $0.018<0.05$. It is also known that the OR value $=0.090$, meaning that Pregnant who have a poor diet are 0.09 times more at risk of suffering from CED compared to Pregnant who have a good diet. The conclusion is that there is a relationship between diet and Chronic Energy Deficiency in first trimester pregnant women at the Pagurawan Health Center, Batu Bara Regency in 2020. So it is hoped that pregnant women will maintain a healthy diet and eat nutritious food so that nutrition during pregnancy is fulfilled.
\end{abstract}

Keywords: Diet, Chronic Energy Deficiency, Pregnant

\section{INTRODUCTION}

Pregnancy is the union of spermatozoa and ovum and is continued by nidation or implantation. When calculated from the time of fertilization to the birth of the baby, a normal pregnancy will take place within 40 weeks according to the international calendar (Walyani, 2015).

Pregnancy is a process that will trigger changes both anatomically, physiologically and biochemically. These changes will greatly affect the nutritional needs of pregnant women which aim to maximize fetal growth and development. The nutritional status of the Pregnant before and during pregnancy affects the nutritional status of the mother and baby. The growth and development of the fetus is strongly influenced by the nutritional intake of the mother, because the nutritional needs of the fetus come from the mother (Sulistyoningsih, 2017).

At a young gestational age (first trimester), women often experience nausea and vomiting (morning sickness). Nausea and vomiting occur due to changes in hormonal levels, namely increased levels of the hormone chorionic gonadortopin (HCG) from the placenta. If the nausea and vomiting become excessive (hyperemesis gravidarum), it will greatly affect the mother's weight so that additional nutrition in the form of vitamins and minerals is needed, while the need for calories and protein is very much needed in the eighth week until birth (Ariani, 2017).

\subsection{Formulation of the problem}

Based on the above background, the formulation of the problem in this study is "is there a relationship between diet and Chronic Energy Deficiency (KEK) in first trimester pregnant women at Pagurawan Health Center, Batu Bara Regency in 2020"? 


\subsection{Research purposes}

This study aims to determine the relationship between diet and Chronic Energy Deficiency (KEK) in first trimester pregnant women at Pagurawan Health Center, Batu Bara Regency in 2020.

a. This study aims to determine the distribution of the diet of pregnant women in the first trimester at the Pagurawan Health Center, Batu Bara Regency in 2020.

b. To Identifity the distribution of Chronic Energy Deficiency in first trimester pregnant women at Pagurawan Health Center, Batu Bara Regency in 2020.

c. This study aims to determine the relationship between diet and Chronic Energy Deficiency in first trimester pregnant women at the Pagurawan Health Center, Batu Bara Regency in 2020 .

\section{LITERATURE REVIEW}

\subsection{Pregnancy}

Pregnancy is divided into 3 trimesters, where the first trimester lasts for 12 weeks, the second trimester is 15 weeks (weeks 13 to 27) and the third trimester is 13 weeks (weeks 28 to 40) (Walyani, 2015).

Pregnancy is a condition in the uterus of a woman there are products of conception (the meeting of the ovum and spermatozoa). Pregnancy is a natural and physiological process. Every woman who has healthy reproductive organs who have experienced menstruation and has sexual relations with a man whose reproductive organs are healthy is very likely to experience pregnancy (Yanti, 2017).

Pregnancy is a manufacturing process in order to continue offspring so as to produce a fetus that grows in a woman's womb. Pregnancy is an important period of life. At this time the mother must prepare herself as well as possible to welcome the birth of her baby. A healthy mother will give birth to a healthy baby. One of the factors that affect maternal health is the nutritional state of the mother (Waryana, 2014).

\subsection{Chronic Energy Deficiency}

Chronic Energy Deficiency (CED) is a condition in which a mother experiences a chronic (chronic) lack of energy and protein, resulting in health problems for the mother, which is characterized of less than $23.5 \mathrm{~cm}$ and looks thin at risk of giving birth to a child. Intra Uterine Growth Retardation (IUGR), Low Birth Weight (LBW) and stunting (Demsa, et al, 2018)

According to the Ministry of Nutrition and Public Health, Indonesia 2014), that Chronic Energy Deficiency (KEK) in pregnant women is a condition resulting from an imbalance between intake to meet energy needs and expenditure. According to Sulistioningsih (2017), pregnant women with Chronic Energy Deficiency have 2.0087 times the risk of giving birth to babies with low birth weight (less than 2500 grams).

Chronic Energy Deficiency (KEK) is a condition of lack of energy and protein intake in women of childbearing age (WUS) and pregnant people that takes place continuously and causes health problems for the mother. The lack of energy and protein intake occurs for a long time, causing the body mass index to be below normal or less than 18.5 for adults (Almatsier, 2015).

Pregnant women must have adequate nutrition because the nutrients obtained will be used for themselves and their fetuses. A mother who does not have or is malnourished during pregnancy, her baby will suffer from malnutrition. If this continues and is not immediately addressed, the baby will be born with a low weight, while for a malnourished mother, as long as she is breastfeeding, little milk is produced (Ariani, 2017).

\subsection{Dietary habit}

Diet is a variety of information that provides an overview of the type and amount of food eaten by one person every day and is a characteristic of a particular community group. Diet is the behavior of humans or a group of humans in meeting the need for food which includes attitudes, beliefs and food choices. Other sources say that eating patterns are defined as characteristics of repeated 
activities of individuals in meeting their needs for food, so that their physiological, social and emotional needs can be met (Sulistyoningsih, 2017).

Diet is defined as the way a person or group of people choose food and consume it as a reaction to physiological, psychological, cultural and social influences. While food is a material that is eaten to meet the body's needs for growth, work and repair of body tissues. In pregnant women, nutritional needs will experience additional needs and are also influenced by nutritional status before she becomes pregnant. This additional need occurs because the growth of the fetus almost completely depends on the supply of nutrients from the body of a pregnant woman (Waryana, 2014).

\section{RESEARCH METHODS}

\subsection{Research Location}

The location of this research was conducted at Pagurawan Health Center, MedangDeras District, Batu Bara Regency, Indonesia The reason for choosing the location is that there are still pregnant women in the working area of the Pagurawan Health Center and research on SEZ has never been done.

\subsection{Research time}

The research was conducted from the submission of the title until the results of the study began in April to September 2020. The time for data collection or collection was from August 1 to August 31, 2020 (for 1 month)

\section{RESEARCH RESULTS AND DISCUSSION}

\subsection{Research result}

\subsubsection{Univariate Analysis Diet for First Trimester Pregnant Women at Pagurawan Health} Center, Batu Bara Regency in 2020

The eating patterns of pregnant women in the first trimester can be known based on the respondents' answers to dietary questions consisting of 20 questions in the category of good eating patterns if they are able to answer correctly 11-20 questions and poor eating patterns if they are only able to answer correctly questions $0-10$ questions. . The categories of eating patterns of pregnant women in

\subsubsection{Data on Chronic Energy Deficiency in first trimester pregnant women}

A pregnant woman is said to have SEZ if her LILA $<23.5 \mathrm{~cm}$. fter measuring LILA for pregnant women, the SEZ data for pregnant women can be seen in the following table:Notation of written mathematical equations should be included at the end of the article before the Bibliography, and given the unit (SI).

Table 1. Frequency Distribution of Chronic Energy Deficiency in First Trimester Pregnant Women at Pagurawan Health Center, Batu Bara Regency in 2020

\begin{tabular}{llll}
\hline No & Chronic Energy Deficiency & Total $(\mathbf{f})$ & Percentage $(\%)$ \\
\hline 1 & KEK & 8 & 15,4 \\
2 & No KEK & 44 & 84,6 \\
\hline & Total & $\mathbf{5 2}$ & $\mathbf{1 0 0}$ \\
\hline
\end{tabular}

Based on table 2 above, it can be seen that there are 8 people (15.4\%) pregnant women who have LILA $<23.5 \mathrm{~cm}$ so that they are categorized as KEK pregnant women. While the other 44 people $(84.6 \%)$ had an LIF $23.5 \mathrm{~cm}$ so they were categorized as not having SEZ.

\subsubsection{Bivariate Analysis}

Bivariate analysis is used to see the relationship between the diet of pregnant women and SEZ can be seen in the following table:

Table 2. Distribution of Relationship between Diet and Chronic Energy Deficiency in First 
Volume 1 No 2 (2021)

Relationship Between Diet Chronic Energy Lack In Pregnant Women In Trimester

DOI: $10.54443 /$ morfai.v1i2.99

Trimester Pregnant Women at Pagurawan Health CenterCoal District in 2020

\begin{tabular}{|c|c|c|c|c|c|c|c|c|c|}
\hline \multirow{3}{*}{ No } & \multirow{3}{*}{ Dietary habit } & \multicolumn{4}{|c|}{ KEK } & \multirow{3}{*}{ Total } & \multirow{3}{*}{$\%$} & \multirow{3}{*}{ OR } & \multirow{3}{*}{ P-Value } \\
\hline & & \multicolumn{2}{|c|}{ KEK } & \multicolumn{2}{|c|}{ NO KEK } & & & & \\
\hline & & $\mathbf{f}$ & $\%$ & $\mathbf{f}$ & $\%$ & & & & \\
\hline 1 & Good & & & & & 28 & 53,8 & & \\
\hline \multirow[t]{3}{*}{2} & Not good & 1 & 1,9 & 27 & 51,9 & 24 & 46,2 & 0,090 & 0,018 \\
\hline & Total & & & & & & & & \\
\hline & & 8 & 15,4 & 44 & 84,6 & 52 & 100 & & \\
\hline
\end{tabular}

Based on the table above, it can be seen that the incidence of SEZ was mostly found in respondents who had a poor diet as many as 7 people (13.5\%) and who had a good diet as many as 1 person (1.9\%). Meanwhile, those who did not experience SEZ were mostly found in respondents who had a good diet as many as 27 people (51.9\%) and a poor diet as many as 17 people $(32.7 \%)$.

The results of this statistical test using the chi-square test (table $2 \times 2$ so that using the fisher exact test) the p-value is $0.018<0.05$. So it can be concluded that there is a relationship between diet and Chronic Energy Deficiency in first trimester pregnant women at the Pagurawan Health Center, Batu Bara Regency in 2020. It is also known that the OR value $=0.090$, meaning that Pregnant who have a poor diet are more at risk of 0.09 more times suffer from CED compared to Pregnant who have a good diet.

\subsection{Discussion}

\subsubsection{Diet for First Trimester Pregnant Women at Pagurawan Health Center, Batu Bara Regency in 2020.}

The results showed that the majority of pregnant women had a good diet (51.9\%) . But not a few pregnant women who have a poor $\operatorname{diet}(32.7 \%)$ When viewed from the respondents' answers, many of them do not regularly eat every day. This is because in the first trimester they often experience nausea and vomiting, thereby reducing the mother's appetite which results in the mother's eating patterns becoming irregular. In addition to the frequency of eating, the schedule and types of food consumed by pregnant women also do not vary. This results in the nutritional needs in one day not meeting the category 4 healthy 5 perfect. The mother may feel that the food eaten is sufficient to meet the needs of her and the fetus. But if the portion is small and the frequency is irregular, especially if the mother experiences nausea and vomiting, then it is certain that her nutritional needs will not be fulfilled. In fact, there are still pregnant women who have abstinence from eating which is a habit or culture that is run in the family so that the discussion of food intake will affect their nutritional state.

A balanced diet consists of a variety of foods in appropriate amounts and proportions to meet a person's nutritional needs. An unbalanced diet will cause an imbalance of nutrients that enter the body and can lead to malnutrition or vice versa, an unbalanced consumption pattern also results in excess of certain nutrients and causes excess nutrition. Lack of nutritional intake in pregnant women during pregnancy in addition to having an impact on Low Birth Weight (LBW).

At the time of the study, there were not a few respondents who were pregnant in the first trimester who were less than 20 years old, therefore respondents who did not receive information or knowledge about nutrition during pregnancy and this led to malnutrition during pregnancy.

Based on the description above, the researcher assumes that diet affects pregnancy with Chronic Energy Deficiency (KEK) because the nutritional state of pregnant women is influenced by imbalances in nutrient intake, food eaten, frequency and portion of food, belief and acceptance of food, such as dietary restrictions and liking or liking. The dislike of food, the daily diet of pregnant women is also influenced by the existence of a belief in abstaining from certain foods to be consumed on the grounds that if consumed during pregnancy it will result in defects in the baby being born so that the food intake of pregnant women becomes less. 


\subsubsection{Chronic Energy Deficiency in first trimester pregnant women at Pagurawan Health Center, Batu Bara Regency in 2020}

Chronic Energy Deficiency can be identified by measuring Upper Arm Circumference (LILA), with the SEZ category if the LILA measurement is $<23.5 \mathrm{~cm}$ and not SEZ if the measurement is 23.5 $\mathrm{cm}$. The results showed that there were 8 people with SEZ in pregnant women in this study. Most of those who experience SEZ are less than 20 years old. Age is still too young, so experience, especially regarding pregnancy, is still minimal, so that eating patterns are not based on knowledge, but suggestions from people around.

According to Budiman and Riyanto (2014), that with increasing age a person will experience changes in physical and psychological (mental) aspects. Broadly speaking, physical growth consists of four categories of changes, namely changes in size, changes in proportions, loss of old characteristics, and the emergence of new characteristics. These changes occur due to the maturation of organ function. On the psychological or mental aspect, a person's level of thinking becomes more mature and mature.

The nutritional status of the mother before and during pregnancy can affect the growth of the fetus being conceived. If the nutritional status of the mother is normal before and during pregnancy, it is likely that she will give birth to a healthy, full-term baby with a normal weight. The quality of the baby born is very dependent on the nutritional state of the mother before and during pregnancy.

Pregnant women who suffer from CED have a greater risk of illness, especially in the third trimester of pregnancy compared to normal pregnant women. As a result, they have a greater risk of giving birth to babies with low birth weight, death during childbirth, bleeding, difficult postpartum because of weakness and easy health problems. Babies born with LBW are generally less able to withstand new environmental pressures, so that it can result in stunted growth and development, and can even interfere with their survival. Increased risk of infant morbidity and mortality due to susceptibility to lower respiratory tract infections, learning disorders, behavioral problems and so on.

\subsubsection{Relationship between Diet and Chronic Energy Deficiency in First Trimester Pregnant Women at Pagurawan Health Center, Batu Bara Regency in 2020}

The results showed that the incidence of SEZ was mostly found in respondents who had a poor diet as many as 7 people (13.5\%) and who had a good diet as many as 1 person (1.9\%). Meanwhile, those who did not experience SEZ were mostly found in respondents who had a good diet as many as 27 people $(51.9 \%)$ and a poor diet as many as 17 people $(32.7 \%)$.

The results of this statistical test using the chi-square test (table $2 \times 2$ so that using the fisher exact test) the p-value is $0.018<0.05$. So it can be concluded that there is a relationship between diet and Chronic Energy Deficiency in first trimester pregnant women at Pagurawan Health Center, Batu Bara Regency in 2020.

The results of this study are in accordance with previous research journals conducted by Wijayanti (2019), that there is a significant relationship between diet and the incidence of chronic energy deficiency in pregnant women with a $\mathrm{P}$ value $=0.001$. There is a relationship between diet and the incidence of KEK because Pregnant who have a good diet will fulfill their nutritional needs during pregnancy because they consume 2 pieces of side dishes for each meal, take vitamins during pregnancy and take blood-boosting drugs. The consumption of side dishes in accordance with the needs of pregnant women causes nutritional needs during pregnancy to be fulfilled as well as Pregnant consume vitamins and blood-boosting drugs during pregnancy, so they will have good immune systems and are rarely exposed to disease so that it has an impact on SEZ. Pregnant women who have a poor diet will tend to experience chronic energy deficiency because the nutritional needs of pregnant women are high, in addition to the mother's own body as well as for the baby.

The results of this study are also in line with Febriyeni's research (2017), which also states that there is a significant relationship between diet and the incidence of chronic energy deficiency in 
pregnant women with a $\mathrm{P}$ value of 0.001 . There is a relationship between diet and the incidence of KEK because Pregnant who have a good diet will fulfill their nutritional needs during pregnancy.

The results of this study are also in accordance with Rahayu's research (2019), that statistical tests obtained $\mathrm{p}$ value $=0.001$ so it can be concluded that there is a relationship between the incidence of CED and eating patterns, so the hypothesis is statistically proven. The nutritional status of pregnant women can be influenced by an imbalance in the intake of the type of food eaten, nutrients, food portions and frequency, beliefs and acceptance of food, such as dietary restrictions and feelings of liking or disliking food. This can affect nutrition in pregnant women. This condition tends to cause the mother to become deficient in certain nutrients such as Chronic Energy Deficiency (KEK).

According to the theory of Sulistyoningsih (2017), that the nutrition of pregnant women is influenced by the OR value $=0.090$, it means that Pregnant who have a poor diet are 0.09 times more at risk of suffering from CED compared to Pregnant who have a good diet. It can be concluded that the better the diet of pregnant women, the better the nutrition so that pregnant women do not experience CED. On the contrary, the less good the diet of pregnant women, the greater the influence on the nutrition of pregnant women so that it will have an impact on SEZ in pregnancy. In this study, it was found that pregnant women who did not experience SEZ but had a poor diet. This condition needs to be considered by pregnant women because it will have an impact on the health of the mother and fetus. Pregnant whose diet is lacking can be indicated that their nutritional needs are not fulfilled so they have the opportunity to have poor nutritional status. If this habit lasts for a long time, pregnant women will be at risk of experiencing CED, even though at the time of the study the condition of pregnant women was categorized as not experiencing CED.

The presence of Pregnant who have a poor diet can be indicated that the mother has the same eating habits as the condition before pregnancy, even though the food needs of pregnant women are 3 times more than before. Based on data obtained in the field, it is known that more pregnant women are housewives every day. This can be indicated that the physical activity carried out as a housewife tends to be lower than Pregnant who work outside the home with a work capacity that requires more energy. This at least reduces the burning of energy in the body which can reduce energy reserves in the body of pregnant women. A person's level of physical activity is related to the type of work. A person with a strenuous level of activity every day and is not balanced with adequate food intake, his body is more susceptible to infectious diseases and results in a chronic lack of energy.

In this study, the presence of pregnant women whose diet is good but experiencing SEZ can be indicated that the food consumed by the mother is inadequate for the body's needs of pregnant women under certain conditions. Adequate food consumption for pregnant women is that if consumed every day can meet the needs of nutrients in quality and quantity. This means that there are pregnant women whose consumption patterns are categorized as good but experience SEZ because in this study it was found that all respondents/pregnant women were in the 1st trimester, which means that the calorie/energy needs of pregnant women are increasing towards the second and third trimesters. Therefore, in this study, although the consumption pattern of pregnant women is said to be good, it is not yet sufficient to support the nutritional needs of pregnant women heading into the second and third trimesters, so there are still pregnant women who have good consumption patterns but are included in the SEZ category.

\section{CONCLUSION}

Based on the results of research obtained about the Relationship between Diet and Chronic Energy Lack (KEK) in First Trimester Pregnant Women at Pagurawan Health Center, Batu Bara Regency in 2020, the following conclusions can be drawn:

1. The diet of pregnant women in the first trimester at the Pagurawan Health Center, Batu Bara Regency is good $(53.8 \%)$. 
2. The number of sufferers of Chronic Energy Deficiency (KEK) in first trimester pregnant women at Pagurawan Health Center, Batu Bara Regency is $15.4 \%$.

3. There is a relationship between diet and Chronic Energy Deficiency (KEK) in first trimester pregnant women at Pagurawan Health Center, Batu Bara Regency in 2020 with a p-value $=0.018$.

\section{REFERENCES}

Almatsier. S. 2015. Basic Principles of Nutrition Science. Jakarta: GramediaPustakaUtama

Ariani, A.P. 2017. Nutrition Science. Yogyakarta: NuhaMedika

Assistance on Changes in Behavioral Nutrition for Pregnant Women with Chronic Energy Deficiency (KEK). Journal of Health Volume 10, Number 2, August 2019 ISSN 2086-7751 (Print), ISSN 2548-5695 (Online) http://ejurnal.poltekkes-tjk.ac.id/index.php/JK

Department of Nutrition and Public Health. 2014. Nutrition and Public Health. Jakarta: PT. King GrafindoPersada

Demsa, S, Rahmadi, A., Jumiyati. 2018. The Effect of Nutritional

Febriyeni. 2017. Factors Associated with the Incidence of Chronic Energy Deficiency in Pregnant Women. Journal of Human Care. e-ISSN:2528-66510;Volume 2;No.3 Year 2017

Hidayat. AA. 2014. Midwifery Research Methods and Data Analysis Techniques. Jakarta: SalembaMedika Irianto, K. 2013. Complete Nutrition Guide: Families and Athletes. Yogyakarta: Andi.

Indonesian Ministry of Health. 2019. Data and Information Profile of Indonesia in 2018. Jakarta: Catalog in Publication

Muliarini, P. 2014. Healthy Diet and Lifestyle During Pregnancy. Yogyakarta: NuhaMedika.

North Sumatra Health Office. 2018. Profile of the North Sumatra Provincial Health Office. Field

Riskesdas. 2018. Basic Health Research. Jakarta: Catalog In Issu.

Rukiyah, AY. 2014. Midwifery Care I (Pregnancy) Revised Edition. Jakarta: Trans Info Media

Siregar, Y.P. 2020. The relationship between diet and the incidence of anemia in pregnant women at the Satria Health Center, TebingTinggi City in 2020. Thesis. LubukPakam: Undergraduate Midwifery Study Program Medistra Health Institute

Sulistyoningsih. 2017. Nutrition for Maternal and Child Health. Yogyakarta: Grahallmu.

Susila, Suyanto. 2014. Research Methods in Medicine and Health Epidemiology. Yogyakarta: Science Exchang.

Waryana. 2014. Reproductive Nutrition. Yogyakarta: Rihama . Library

Walyani, ES. 2015. Midwifery Care in Pregnancy. Yogyakarta: New Library Press

Wijayanti. I.T. 2019. Eating Patterns of Pregnant Women Affecting SEZ Incidence at the Gabus I Health Center, Pati Regency. SMART Journal of Midwifery, 2019, 6 (1), 5-9 @SJKB 2019 DOI: 10.34310/sjkb.v6i1.226 pISSN 2301-6213; eISSN 2503-0388 http://stikesyahoedsmg.ac.id/ojs/index.php/sjkb

Yanti, D. 2017. Basic Concepts of Pregnancy Care. Bandung: RefikaAditama

Notes :

Thank's A Lot To Radja Publika As The Head Officer Of Ijebas Journal Who Has Facilitated The Process Of Publishing This Scientific Article And Also Especially To Lppm Universitas Malikussaleh. Who Is Willing To Cooperate In The Process Of Publishing Articles About Relationship Between Diet Chronic Energy Lack In Pregnant Women In Trimester. 
Volume 1 No 2 (2021)

Relationship Between Diet Chronic Energy Lack In Pregnant Women In Trimester DOI: $10.54443 /$ morfai.v1i2.99 